\author{
POR \\ RENÉ DE Costa \\ The University of Chicago
}

La poesía, lo que se suele considerar verdadera poesía, es algo que nos asalta por sorpresa. En contraste con aquellos versos cantarines que nos obligaron a memorizar de niños y que han quedado grabados indeleblemente en nuestra memoria lingüística, la poesía, la verdadera poesía, es un descubrimiento personal. De pronto, un conjunto de palabras cobra un sentido único y, con frecuencia reservado sólo para nosotros. Por esta razón la experiencia poética, a la que sucumbimos sin esfuerzo, es por lo general de difícil explicación, sobre todo cuando pretendemos hacerlo con otras palabras. Y por esta misma razón, los lectores de poesía son implacables cuando detectan la voz o la imaginería de un poeta conocido en los versos de otro. Exigimos originalidad y rechazamos, casi visceralmente, la repetición. Dejamos de leer un nuevo libro de poemas cuando tenemos la sensación de que aquello ya lo leímos en otra parte, que otro poeta ya lo dijo antes.

No sucede esto con el catalán Joan Brossa y el chileno Nicanor Parra, dos contemporáneos, geográfica y lingüísticamente distantes, radicalmente singulares dentro de sus distintas tradiciones literarias, y sin embargo tan próximos desde el punto de vista temático y conceptual que, cuando leemos a ambos, tenemos la sensación de estar descubriendo nuevas facetas de una misma personalidad creativa. Esto fue al menos mi impresión cuando llegué a Brossa después de conocer a Parra, y cuando regresé a Parra después de haber leído a Brossa.

Coincidencia curiosa ya que no hay comunicación directa entre Barcelona y Santiago de Chile. Aunque de hecho, en el itinerario poético de ambos autores hay un punto crucial en los años 1950 cuando ambos, cada uno por su lado, descubre, o más bien crea, un nuevo mundo, el mundo de la "antipoesía", escritura sin pretensión, en lenguaje cotidiano, registrando el diario suceder, como en este poema de Brossa en su primer libro de 1951, Em va fer Joan Brossa:

Un home esternuda.

Passa un cotxe.

Un botiguer tira la porta de ferro avall.

\footnotetext{
' Ensayo preparado con motivo de una exposición de la poesía visual y conversacional de Brossa y Parra en Valencia y Chicago (marzo-diciembre, 1992).
} 


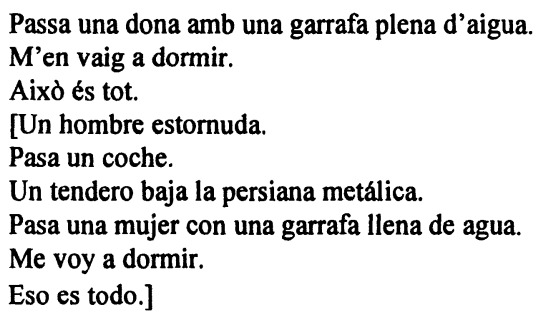

Este tipo de discurso llano, frío, expositivo, nos hace pensar en Parra, el de los primeros Poemas y antipoemas, libro de 1954. Allí se incluía una "Advertencia al lector", para ponerle en antecedentes, advertirle sobre lo que iba a encontrar, o mejor, sobre lo que no iba a encontrar:

Según los doctores de la ley este libro no debiera publicarse:

La palabra arco iris no aparece en él en ninguna parte,

Menos aún la palabra dolor,

La palabra torcuato.

Sillas y mesas sí que figuran a granel,

¡Ataúdes!, ¡útiles de escritorio!

Lo que me llena de orgullo

Porque, a mi modo de ver, el cielo se está cayendo a pedazos.

Esta misma clase de "advertencia", esta misma conciencia de lo que ya no tiene por qué estar en un poema, la encontramos también en Brossa. A propósito, lo que el uno llamaba "antipoesía", el otro llamaba "poesía cotidiana". Nombres nuevos para algo nuevo. En $E l$ cigne i l'oc (1964), advierte Brossa:

No os conduiré a cap roser en flor, ni us parlaré de lliris i violetes, ni d'ulls lents ni de terres blaves can una taronja; tot això ha esdevingut tan corrent en poesia com gran qualitat o durada extraordinària en propaganda comercial.

[No os llevaré a ningún rosal en flor, ni os hablaré de lirios y violetas, ni de miradas lentas ni de tierras azules como una naranja; todo esto ha llegado a ser tan corriente en poesía como gran calidad o duración extraordinaria en propaganda comercial.]

Brossa y Parra comparten una misma actitud frente al lenguaje. No como trampolín de vanguardia para hacer saltar imágenes nuevas, sino como vehículo para decir algo nuevo, o como contenedor de ideas nuevas encerradas en las frases hechas: la peculiar autoridad de aquel locutor anónimo que nos reta cómo debemos comportarnos en el bus, en el cine, en el taxi. 
Nuestros dos poetas coincidieron años atrás al intrigarse por la fuerza autoritaria de este tipo de discurso. En Poemas de París, libro de 1956, tenemos este texto breve de Brossa, una especie de poème-trouvé:

\section{EL MUSEU}

\section{L'art de Nouristan}

S'escapa de la influència

Islàmica del segle VII l'any

18 ... etcètera

NO FUMEU, SI US PLAU, A LES SALES.

[El arte de Nouristan

Se escapa de la influencia

islámica del siglo séptimo en el ańo

mil ochocientos ... etcétera

¡NO FUMAR, POR FAVOR, EN LA SALA!]

Y Parra, en este poema de Canciones rusas (1967), utiliza la técnica de la "enumeración caótica" para hacer una especie de recopilación irónica de un surtido variado de "advertencias":

\footnotetext{
Se prohibe rezar, estornudar, Escupir, elogiar, arrodillarse, Venerar, aullar, expectorar. En este recinto se prohibe dormir, Inocular, hablar, excomulgar, Armonizar, huir, interceptar.
}

Estrictamente se prohibe correr.

¡Se prohibe fumar y fornicar!

Estas semejanzas, estas convergencias se basan en una misma idea compartida: que a estas alturas de la vida y de la literatura "todo está dicho", y no tiene sentido volver a escribir lo ya escrito sobre el amor, la muerte, la angustia ...

Como dice Brossa: "en los libros de poesía es precisamente donde menos se encuentra la poesía"; 2 o como dice Parra, refiriéndose seguramente a Juan Ramón y a la encumbrada generación del '27: "durante medio siglo la poesía fue el paraíso del tonto solemne". 3

En poesía, hay que hacer cosas nuevas -y ¡está estrictamente prohibido escribir un poema ya escrito!- hay que decir cosas nuevas, y en el lenguaje en que habla la gente: no

\footnotetext{
${ }^{2}$ Declaración a J. Cuillamon, Avui (Barcelona, 20-I-85).

${ }^{3}$ En "La montaña rusa", Versos de salón (1962).
} 
en esta jerga fina que no habla nadie. El resultado, en algunos casos - realmente sorprendente- es que los dos, Brossa y Parra, han llegado a escribir el mismo poema, aunque con medios diferentes. Pondré dos ejemplos, uno convergente y otro divergente.

El primero se basa en el reciclaje del habla común, cuya genial originalidad ha quedado plasmada en frases hechas, refranes, clichés. Este poema es de un volumen titulado Poemes civils (1961):

Callar és sac d'errades.

Més val perdiu en mà que dues en l'aire.

Escoltaràs, miraràs i si res veus ho callaràs.

Qui no s'arrisca no passa el mar.

Home, com quedem?

[Callar es fuente de errores.

Más vale perdiz en mano que dos volando.

Eschucharás, mirarás y si ves algo callarás.

Quien no se arriesga no gana.

Hombre, ¿en qué quedamos?]

Y este otro de Parra, titulado "Frases", es de su Obra gruesa (1969):

No nos echemos tierra a los ojos.

El automóvil es una silla de ruedas.

El león está hecho de corderos.

Los poetas no tienen biografía.

La muerte es un hábito colectivo.

Los niños nacen para ser felices.

La realidad tiende a desaparecer.

Fornicar es un acto diabólico.

Dios es un buen amigo de los pobres.

En un ejemplo la gracia está en la yuxtaposición de refranes; en el otro en la modificación de clichés. En ambos, hay una progresión, un remate que nos sacude, obligándonos a revalorizar estéticamente lo que hemos leído.

Ésta no es una poesía de "guante blanco", escrita desde el Olimpo. "Los poetas bajaron del Olimpo", como dijo Parra en un "Manifiesto" de 1963:

\footnotetext{
Señoras y señores

Ésta es nuestra última palabra.

- Nuestra primera y última palabra-

Los poetas bajaron del Olimpo.
}

La solemne postura del vate visionario pertenece de pronto al pasado; la sintaxis tortuosa de la escritura elegante se torna caduca frente a la claridad directa del lenguaje 
cotidiano. Un poema, un verdadero poema, ya no tiene por qué ser algo complicado, fuera del alcance del lector común y corriente, sino una secuencia de imágenes que golpean nuestra sensibilidad con el impacto de un relámpago, produciendo el choque de sorpresa tan programáticamente perseguido por la vanguardia histórica.

Ambos poetas, Parra y Brossa, deben mucho a Dadá y al Surrealismo, y de hecho, se constituyen en la neo-vanguardia de nuestro tiempo. Sus "poemas-objetos" y sus "artefactos", recogen - para continuar- las experiencias de Duchamp allí donde él las dejó, transformando los objets-trouvés en objetos artísticos a través de un golpe de mano, como de prestidigitador. Un ejemplo: Brossa toma dos hojas (de árbol) y las junta con un clip, algo que sería insignificante si no fuera por el título: "Burocràcia", que pone en funcionamiento una serie de relaciones que convierten las hojas de árbol en hojas de papel con el mensaje subliminal de la trivialidad del papeleo burocrático. Parra hace otro tanto, atravesando un tomate con un clavo, al que luego añade un título "Naturaleza muerta"; pero que además, cuando lo miramos de cerca, cuando vemos que el tomate es de plástico, resulta ser una naturaleza doblemente muerta.

Esta yuxtaposición de lo visual con lo verbal tiene también una dimensión sociopolítica. En uno de los Artefactos (1972) de Parra, un dibujo a línea que representa la Estatua de la Libertad, vemos la leyenda: "USA, donde la libertad es una estatua". Publicado en su día como una tarjeta postal, fue transformado después en arte público, al ser trasladado al noticiario iluminado del edificio Times en el centro de Nueva York en marzo de 1987. El arte público de Brossa es menos efímero. En 1984 hizo erigir un poema visual "transitable" para la entrada del Parque del Velódromo en Barcelona, el cual consistía en un arco gigante en forma de la letra "A", el comienzo del alfabeto. A continuación el transeúnte ve la misma letra en vías de ser ruina, rodeada por los signos diacríticos caídos al suelo. Todo es perecedero.

En la España franquista de los sesenta, cuando el catalán era un idioma proscrito, Brossa usa un ícono visual en un poema que sólo tiene una palabra en catalán:

La bandera bicolor, roja y gualda, como pabellón de Espaffa.

Un estanc.

La última palabra, estanc, que aparece al final como una errata, transforma el conocido logotipo del monopolio estatal del tabaco en un símbolo de la dominación imperial, una imagen reforzada por el símil de la bandera camo pabellón, estampa de colegio de la triunfante colonización de los castellano-parlantes allende los mares. El mensaje político de ambos poemas es sutil y rotundo, pero sobre todo difícil de ser manipulado por la censura ya que lo que se expresa abiertamente es una simple verdad. Es el lector quien añade la interpretación política.

En un nivel más complejo, esta poesía también "encuentra" sus "objetos" en la retórica rutinaria del lenguaje de la iglesia o del estado. En "Escamoteig de cinq poemes", Brossa nos ofrece un extracto de un documento oficial: 


\title{
L'OFICI
}

... Esta Dirección General de Información, a propuesta del Servicio correspondiente, ha decidido:

Resolver dicha solicitud, en las condiciones indicadas en la hoja adjunta.

Dios guarde a Vd. muchos años.

Madrid, 24 de febrero de 1960.

\section{EL PAPER ADJUNT}

Suprímanse los poemas en páginas 33 , $45,60,64,70$ (los sonetos suprimidos en rojo), y preséntese galerada impresa.

Aquí, es el título y el arreglo tipográfico lo que proporciona al lector una clave visual, obligándonos a leer el "oficio" como poesía, descubriendo así su sentido profundo.

Parra hace lo mismo cuando toma el clásico discurso de un predicador para darse otra voz, voz de arenga para así poder hablar de política en el régimen represivo de Pinochet:

\section{CRISTO DE ELQUI SE MAUNDA LAS PARTICULAS EN EL PARQUE COUSIÑO}

\author{
Para serles sincero ... \\ Hay solamente uno \\ que está libre de toda sospecha \\ ustedes saben a quien me refiero. \\ La mentira \\ proviniendo de Él \\ por morrocotuda que sea \\ es palabra sagrada. \\ ¡Pobre del que pensare lo contrario! \\ ¡Será ejecutado en el lugar de los hechos \\ si es que no ha sido ejecutado antes!
}

También el lenguaje comprimido de los anuncios por palabras en la prensa es fuente de inspiración para los dos. Brossa transforma un simple anuncio de hotel en la denuncia de un nuevo tipo de colonización:

\section{PAUMA E MALLORCA}

Best situation view to the bay and to the wood. Rooms with all comfort, private bath, telephone in every room. Bar Service and Restaurant. Beste Lage. Aussicht auf Hafen 
und Wald. Zimner mit allem Konfort einschliesslich Bad und Telephon.

Eigene Bar und Restaurant.

Y Parra se apropia del lenguaje idealizante de los que "se ofertan" para lanzar un mensaje aderezado de ironía jocosa:

Caballero de buena voluntad

Apto para trabajos personales

Ofrécese para cuidar señorita de noche

Gratis

sin compromisos de ninguna especie.

Seriedad absoluta

Disposición a contraer matrimonio

Siempre que la señorita sepa mover las caderas.

El juego de palabras es fundamental para ambos poetas. $\mathrm{Y}$ en un caso concreto, parece como si Brossa y Parra hubieran creado dos variantes individuales del mismo poema: "Oda a Marx" (una foto del mar revuelto a que Brossa anade una "X") y "Los rollos del Mar(x) muerto" (rótulo que pone Parra a una edición de El capital) ya que ambos textos se apoyan en la lectura de Marx como mar.

En todavía otro caso, los dos encuentran su inspiración en el mismo producto de la tecnología moderna: el TAV, el Tren de Alta Velocidad que atraviesa enormes distancias en nada de tiempo. Brossa hace un poema visual, "TREN", en realidad un logotipo -un tren con dos máquinas en cabecera y cola - para ser pintado a lo largo del TAV español, diseñado de tal manera que produce la sensación de que el tren se mueve simultáneamente en los dos sentidos, que está llegando y partiendo al mismo tiempo. El poema de Parra es totalmente verbal, aunque titulado "Proyecto de tren instantáneo":

La locomotora del tren instantáneo está en el lugar de destino (Pto. Montt) y el último carro en el punto de partida (Stgo.)

La ventaja que presenta este tipo de tren consiste en que el viajero llega instantantáneamente a Puerto Montt en el momento mismo de abordar el último carro en Santiago

lo único que debe hacer a continuación es trasladarse con sus maletas por el interior del tren hasta llegar al primer carro 


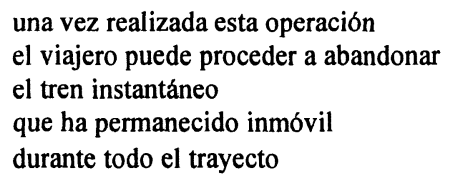

Y así sucesivamente, ambos artistas van transformando los clichés, las frases hechas, la retórica vacía, los grandes inventos de nuestra sociedad moderna, en creaciones verbales y visuales que son como revulsivos ya que sacuden nuestra mente, generando en su lectura una suerte de complicidad entre el autor y el perceptor. Pero no todo es igual. El temperamento creativo y el bagaje cultural de cada uno de estos artistas genera un producto distinto, da un sello particular a sus trabajos, que son tan semejantes como singulares: la ironía corrosiva que marca el trabajo de Parra, la pulcritud conceptual que caracteriza el de Brossa, y la gran carga de humor que une a ambos. A lo largo de sus respectivas trayectorias, Parra es más verbal y Brossa más plástico, aunque ambos son fundamentalmente histriónicos, showmen de primera magnitud. Una faceta importante de la producción de Brossa es su Poesia escènica de los años cincuenta, guiones anticipatorios para lo que vendría a denominarse Happenings. Los recitales de Parra, sin guión, son a su vez una especie de performance art. Un poema, inédito todavía, es como un anuncio teatral:

\section{EL TEATRO SIN PÚBLICO}

Sólo para actores y dramaturgos

Se prohibe estrictamente la entrada

Multas adultos 300

estudiantes 100

Uno de sus "artefactos dramáticos" se titula "Contaminación" y consiste simplemente "en incendiar un neumático en el escenario a puertas y ventanas cerradas". Parra lleva lo convencional hasta lo ridículo, y provoca una sonrisa; Brossa utiliza lo ridículo para hacernos reflexionar sobre su recóndito significado. A modo de ejemplo, reproduzco un texto breve de Brossa, titulado "Poema per a representar".

Lloc: dues habitacions qualssevol, que recorre 1'espectador acompanyat de 1'actor.

\section{Primera habitació}

Damunt una taula, un rodet de fil blanc i una oliva.

\section{Segona habitació}

Damunt una taula, un rodet sense fil i un pinyol d'oliva. 
Innumerables ejemplos más de convergencias y de divergencias asaltarán al lector/ espectador que va mirando/leyendo los trabajos de Parra y de Brossa, dos espíritus hermanos - parecidos como hermanos, diferentes como hermanos - que han cambiado y enriquecido el arte visual y verbal de nuestro tiempo, permitiéndonos ver más allá de las palabras y de la literatura. Esto es en definitiva lo que es poesía, la verdadera poesía. 
